\title{
PERLAKUAN AKUNTANSI TERHADAP PENERIMAAN DAN PENGELUARAN KAS PADA LPD (LEMBAGA PERKREDITAN DESA) PAKRAMAN DHARMAJATI TUKADMUNGGA
}

\author{
Putu Agus Putrayasa \\ Jurusan Akuntansi Program Diploma III \\ Universitas Pendidikan Ganesha, Singaraja \\ e-mail: Putrayasa33@yahoo.com
}

\begin{abstract}
Abstrak
Penelitian bertujuan untuk mengetahui perlakuan akuntansi terhadap penerimaan dan pengeluaran kas serta penyajian kas kedalam laporan keuangan pada LPD Desa Pakraman Dharmajati Tukadmungga Pengumpulan data menggunakan metode observasi, wawancara, dan dokumentasi. Data yang digunakan adalah data kualitatif berupa penjelasan perlakuan akuntansi terhadap penerimaan dan pengeluaran kas, sumber penerimaan kas dan pengeluaran kas, struktur organisasi beserta tugas dan wewenang dari masing-masing bagian serta sejarah berdirinya perusahaan. Selanjutnya data dianalisis dengan analisis deskriptif komparatif.

Hasil penelitian menunjukkan bahwa (1) perlakuan akuntansi terhadap penerimaan dan pengeluaran kas yang diterapkan oleh LPD Desa Pakraman Dharmajati Tukadmungga sesuai dengan Standar Akuntansi Keuangan yang berlaku umum, kas diakui atas dasar biaya historis, dimana kas dicatat sebesar nominal transaksi yang terjadi. (2) Laporan keuangan yang dihasilkan oleh LPD Desa Pakraman Dharmajati Tukadmungga adalah laporan neraca dan laporan laba/rugi, laporan yang berhubungan dengan kas adalah laporan neraca.
\end{abstract}

Kata Kunci : Perlakuan Akuntansi, Penerimaan, pengeluaran kas

Abstract

This study aims to determine the accounting treatment of cash receipts and disbursements as well as the presentation of cash into the financial statements of the LPD Pakraman Dharmajati Tukadmungga. The techniques used for data collection are observation, interview, and documentation methods. The data used are qualitative data in the form of an explanation of the accounting treatment of cash receipts and , the source of cash receipts and disbursements, along with the organizational structure of the duties and authority of each section as well as the history of the company. Furthermore, the data will be analyzed with descriptive comparative analysis that compares the accounting treatment of cash receipts and payments that are applied by the company with existing theories.

The result shows that (1) the accounting treatment of cash receipts and payments are applied by LPD Dharmajati Tukadmungga are in accordance with Financial Accounting Standards generally accepted; cash recognized on the basis of historical cost, which are recorded at nominal cash transactions. (2) The financial statements produced by LPD Pakraman Dharmajati Tukadmungga are the balance sheet and income / loss, statements relating to cash is the balance sheet.

Keywords : Accounting Treatment, Receipts and disbursements, Financial Reports. 


\section{Pendahuluan}

Didalam sebuah perusahaan, perusahaan apapun pastinya selalu ingin memenuhi kebutuhan seorang yang mampu memberikan keuntungan perusahaannya, dalam hal ini LPD atau lembaga perkreditan desa dalam melaksanakan usahanya selalau ingin memenuhi kebutuhan seorang nasabah, karena nasabah adalah orang yang mampu memberikan keuntungan bagi LPD dari bunga pinjaman yang dibayar nasabah. LPD dalam suatu desa sangat penting perannya, terutama dalam memberantas masyarakat miskin yang berada dalam suatu desa, karena LPD dapat membantu masyarakan yang membutuhkan dana dan memiliki tingkat bunga yang tidak terlalu besar dan juga mudah untuk melakukan suatu pinjaman. Penyaluran dana kepada usaha-usaha produktif di daerah pedesaan, tentu akan berkontribusi terhadap peningkatan pendapatan regional daerah Bali. Di samping itu, dengan semakin berkembangnya usaha - usaha masyarakat yang dibiayai oleh LPD, maka usaha tersebut akan menyerap tenaga kerja yang lebih banyak. Ini berarti banyaknya pengangguran terutama di Bali dapat diatasi.

Dari sudut pandang masyarakat, keberadaan LPD yang sehat, akan sangat membantu, baik secara ekonomi maupun sosial. Secara ekonomis, masyarakat memiliki alternatif untuk menyimpan dananya secara produktif dengan memperoleh pendapatan bunga yang bersaing dengan lembaga keuangan lainnya. Sementara bagi masyarakat yang membutuhkan dana, LPD biasanya merupakan pilihan utama, karena mereka dapat meminjam dana dengan prosedur yang tidak berbelit-belit. Dampak sosial dari keberadaannya, tercermin dari taatnya setiap LPD dalam memenuhi isi peraturan daerah dan surat keputusan gubernur yang mewajibkan LPD untuk menyumbangkan 20\% keuntungannya untuk dana pembangunan desa dan 5\% untuk dana sosial. Hal ini akan meringankan beban masyarakat, karena mereka tidak perlu memikirkan iuran pembangunan desa dan dana sosial, setidak-tidaknya, sebesar yang telah disumbang oleh LPD.

LPD merupakan penyediaan jasa keuangan yang bersifat sosial kemasyarakatan, dari dan untuk masyarakat kembali, sehingga kegiatan usahanya memiliki karakter khas, yang merupakan usaha yang didasarkan pada kepercayaan dan banyak menanggung resiko. Karena LPD merupakan usaha simpan dan pinjam yang berarti menghimpun dana atau menyimpan dana dari masyarakat dan menyalurkannya kembali dalam bentuk kredit pada masyarakat, maka pengelolaan harus dilakukan secara profesional dan ditangani oleh pengelola yang memiliki keahlian dan kemampuan yang khusus.

Dalam menjalankan usahanya yaitu menghimpun dan menyalurkan dana, LPD (lembaga perkreditan desa) sangat berhubungan erat dengan kas baik disisi penerimaan kas maupun pengeluaran kas, dimana dalam melakukan penghimpunan dana akan menimbulkan adanya penerimaan kas dan pada saat melakukan penyaluran dana akan menyebabkan adanya pengeluaran kas. Jadi disini transaksi penerimaan dan pengeluaran kas sangatlah sering terjadi pada lembaga perkreditan desa, oleh sebab itu diperlukan adanya perlakuan akuntansi yang baik. Perlakuan akuntansi adalah suatu tindakan atau perbuatan yang dilakukan oleh seseorang dalam bentuk pencatatan, penggolongan peringkasan, pelaporan dan penganalisa data keuangan, serta menafsirkan hasil-hasil laporan keuangan.

Perlakuan akuntansi berguna untuk mengatur adanya pengakuan, penilaian dan penyajian terhadap kas agar nantinya kas dapat disajikan dengan lebih relevan dan wajar pada laporan keuangan yang dibuat. Kas merupakan aktiva yang paling likuid dan juga hampir seluruh kegiatan operasional di LPD (Lembaga Perkreditan desa) akan menyangkut masalah kas atau berakhir kas, untuk itu kas selayaknya mendapatkan penanganan yang terbaik, baik dari sisi penerimaan maupun dari sisi pengeluarannya.

Kelalaian dalam penanganan kas baik penerimaan maupun pengeluaran akan sangat mempengaruhi kondisi keuangan yang sudah diproyeksikan sehingga nantinya akan menghambat pencapaian tujuan perusahaan dalam hal ini pada Lembaga Perkreditan Desa. Kekeliruan dalam pencatatan akuntansinya baik karena disengaja maupun tidak sengaja 
prinsip-prinsip akuntansi yang berlaku umum akan mempengaruhi layak atau tidaknya dari laporan keuangan yang dihasilkan, yang akhirnya akan merugikan pihak-pihak pemakai dan yang berkepentingan terhadap laporan keuangan tersebut.

LPD (Lembaga Perkreditan Desa) Pakraman Dharmajati Tukadmungga merupakan salah satu lembaga yang mengalami perkembangan cukup pesat. LPD yang beralamat di Desa Tukadmungga Jalan Prawira Darma Kabupaten Buleleng ini mempunyai atau melakukan kegiatan operasional yang sama dengan LPD lainnya yaitu menghimpun dana dari masyarakat dan menyalurkannya kembali ke masyarakat dalam bentuk kredit yang tentunya sangat berhubungan dengan kas baik itu penerimaan maupun pengeluarannya. Dalam perlakuan akuntansi penerimaan dan pengeluaran kas yang dilakukan di LPD (Lembaga Perkreditan Desa) Pakraman Dharmajati Tukadmungga sudah berjalan cukup optimal. Pencatatan dilaksanakan dengan sistem komputerisasi dan manual hal ini dilakukan untuk mengurangi adanya kesalahan pencatatan.

\section{Metode Penelitian}

Tujuan yang ingin dicapai dari penelitian penelitian ini adalah untuk mengetahui perlakuan akuntansi terhadap penerimaan dan pengeluaran kas pada LPD (lembaga perkreditan desa) pakraman dharmajati tukadmungga. Pada penelitian ini, data yang dipergunakan adalah data kualitatif yang merupakan fokus utama dari tujuan penelitian. Agar tujuan peneliti dapat tercapai, maka peneliti mengumpulkan data dengan menggunakan metode wawancara yaitu pengumpulan data dengan mengadakan wawancara secara langsung dengan staf karyawan/ karyawati LPD (Lembaga Perkreditan Desa) Pakraman Dharmajati Tukadmungga, misalnya bagaimana perlakuan akuntansi penerimaan dan pengeluaran kas yang diterapkan. Metode dokumentasi yaitu pengumpulan data data yang dilakukan melalui catatan-catatan atau dokumen yang ada LPD (Lembaga Perkreditan Desa) Pakraman Dharmajati Tukadmungga misalnya buku kas kasir LPD (Lembaga Perkreditan Desa) Pakraman Dharmajati Tukadmungga. Metode observasi yaitu pengumpulan data dengan cara pengamatan dan meneliti secara langsung perlakuan akuntansi terhadap penerimaan dan pengeluaran kas pada LPD (Lembaga Perkreditan Desa) Pakraman Dharmajati Tukadmungga. Data yang telah terkumpul akan dianalisis dengan analisis deskriptif komparatif. Analisis ini menggambarkan perlakuan akuntansi penerimaan dan pengeluaran kas pada LPD (Lembaga Perkreditan Desa) Pakraman Dharmajati Tukadmungga yang kemudian dibandingkan dengan perlakuan akuntansi penerimaan dan pengeluaran kas menurut teori akuntansi yang berlaku umum dan atau buku penujang lainnya.

\section{Hasil dan Pembahasan}

Proses akuntansi LPD Desa Pakraman Dharmajati Tukadmungga berawal dari dilakukannya pencatatan ke semua transaksi dalam bukti dasar yaitu bukti kas masuk (BKM) dan bukti Kas keluar (BKK), namun ada beberapa transaksi yang dicatat di bukti dasar dan dibuku kasir, diantaranya pada saat adanya penerimaan tabungan, penerimaan angsuran kredit dan pengeluaran pada saat adanya penarikan tabungan dari nasabah. Setelah dilakukan pencatatan semua transaksi kedalam bukti kas masuk dan bukti kas keluar kemudian dari bukti tersebut akan diposting kedalam buku besar berupa daftar mutasi transaksi harian yang kemudian menghasilkan laporan keuangan berupa neraca harian yang sudah termasuk perhitungan laba/rugi didalamnya, untuk laporan keuangan perbulan dan laporan keuangan tahunan LPD Desa Pakraman Dharmajati Tukadmungga yang dibuat yaitu neraca dan laporan laba/rugi, laporan neraca dan laporan laba/rugi ini dibuat dengan melihat neraca harian LPD pada akhir bulan begitu juga laporan akhir tahun sama, yaitu melihat neraca harian akhir tahun. Perlakuan akuntansi bertujuan untuk mengatur Pengakuan, Pengukuran dan Penilaian serta 
Pengidentifikasian agar nantinya dilaporan keuangan dalam hal ini kas yang tertera dalam neraca dapat diuji kebenarannya.

\section{a. Pengakuan}

Pada LPD Desa Pakraman Dharmajati Tukadmungga akun kas digunakan untuk semua transaksi penerimaan maupun pengeluaran kas melalui kasir. Penerimaan dan pengeluaran kas di akui dan dicatat saat kas tersebut sudah diterima dan sudah benar-benar di lakukan pengeluaran. Pencatatan transaksi keuangan yang layak akan dapat menghasilkan laporan keuangan yang layak juga, dimana laporan keuangan merupakan hasil dari proses akuntansi. Proses pencatatan akuntansi harus dapat dicatat secara kronologis, artinya kas harus dicatat sesuai dengan urutan kejadian sejak kas dikeluarkan sebagai kredit sampai kas diterima kembali. Keadaan tersebut akan dapat dicapai apabila perusahaan mampu menciptakan suatu koordinasi kerja yang baik, sehingga dapat mendukung adanya prosedur pencatatan secara benar.

Dalam hal pengeluaran kas, LPD Desa Pakraman Dharmajati Tukadmungga tidak membentuk dana kas kecil, pengeluaran sekecil apapun akan di ambil dari kas besi yang ada di kasir. Berdasarkan SAK 2009:15, pengakuan (recognition) merupakan proses pembentukan pos yang membawa manfaat ekonomi dimasa mendatang serta memiliki nilai yang dapat diukur dengan andal. Dalam hal ini Pencatatan kas pada LPD Desa Pakraman Dharmajati Tukadmungga sudah sesuai dengan SAK Umum yang dilakukan pada saat kas secara fisiknya sudah benar-benar diterima dan dikeluarkan, dalam hal ini pengakuan kas dilakukan dengan metode cash basis.

b. Pengukuran dan Penilaian

LPD Desa Pakraman Dharmajati Tukadmungga dalam hal pengukuran dan penilaian menggunakan asas biaya historis. Biaya historis yaitu aset dicatat sebesar pengeluaran kas atau setara kas yang dibayar atau sebesar nilai wajar dari imbalan yang diberikan untuk memperoleh aset tersebut pada saat perolehan. Menurut

SAK 2009: 15-18, penilaian dan pengukuran dalam akuntansi umum didasarkan pada penilaiannya atas dasar probabilitas manfaat ekonomi masa depan dan keandalan pengakuan serta pengukuran penilaiannya atas dasar biaya historis, biaya kini, nilai realisasi, nilai sekarang. Dalam hal ini, pengukuran dan penilaian pada LPD Desa Pakraman Dharmajati Tukadmungga yang digunakan sudah sesuai teori yang berlaku yaitu menggunakan asas biaya historis. Untuk saldo kas dinilai sesuai dengan jumlah fisik kas per tanggal laporan.

c. Pengidentifikasian

LPD Desa Pakraman Dharmajati Tukadmungga membuat laporan keuangan berupa Lapoan Neraca dan Laporan Laba/Rugi, sebelum dibuatnya laporan keuangan akan dilakukan pengidentifikasian terlebih dahulu terhadap transaksi-transaksi yang terjadi melalui bukti-bukti transaksi, begitu juga halnya dengan kas. Saldo kas yang tertera dilaporan keuangan sebelumnya juga sudah dilakukan pengidentifikasian dengan melihat bukti-bukti transaksi seperti BKK, BKM, nota, kwitansi dan dokumen lainnya agar kas yang ada di laporan keuangan menjadi relevan. Hal ini sesuai dengan SAK dan teori yang berlaku umum bahwa dalam penyusunan laporan keuangan harus berdasarkan bukti-bukti transaksi yang relevan.

Laporan keuangan yang dihasilkan oleh LPD Desa Pakraman Dharmajati Tukadmungga setelah semua transaksi penerimaan dan pengeluaran kas diposting kedaftar mutasi transaksi harian yaitu berupa Laporan Neraca harian yang termasuk laba atau rugi didalamnya. Untuk laporan keuangan bulanan dan laporan keuangan tahunan yang dibuat oleh bagian Tata Usaha LPD dalam penyajiannya di laporan neraca, kas LPD Desa Pakraman Dharmajati Tukadmungga ini akan dicantumkan yakni pada aktiva lancar sebesar jumlah fisik kas yang ada berdasarkan catatan yang ada di neraca harian per tanggal kejadian yang sebelumnya telah diakui kebenarannya, neraca disajikan dengan memisahkan kas dengan aktiva lancar lainnya. Menurut PSAK No 1 (Revisi 1998) Perusahaan menyajikan aktiva lancar terpisah dari aktiva 
tidak lancar dan kewajiban jangka pendek terpisah dari kewajiban jangka panjang kecuali untuk industri tertentu yang diatur dalam SAK khusus. Dalam hal ini pencatatan kas ke dalam Laporan Neraca LPD Desa Pakraman Dharmajati Tukad mungga sudah sesuai dengan PSAK. Didalam Laporan Laba/Rugi yang ada di LPD Desa Pakraman Dharmajati Tukadmungga sama seperti pembuatan neraca yaitu melihat neraca harian LPD per tanggal kejadian karena neraca harian telah termasuk laba didalamnya, yang dibuat hanya perbandingan antara pendapatan yang diterima perharinya dengan beban atau biaya yang terjadi selama satu hari tersebut. Menurut PSAK No 1 (Revisi 1998) Laporan Laba/Rugi perusahaan disajikan sedemikian rupa yang menonjolkan berbagai unsur kinerja keuangan yang diperlukan bagi penyajian secara wajar. Laporan Laba/Rugi minimal mencakup pos-pos pendapatan, laba rugi usaha, beban pinjaman, bagian dari laba atau rugi perusahaan afiliasi dan asosiasi yang diperlakukan menggunakan metode ekuitas. Dalam hal ini Laporan Laba/Rugi LPD Desa Pakraman Dharmajati Tukad mungga sudah sesuai dengan PSAK.

\section{Simpulan dan Saran}

Berdasarkan hasil pembahasan yang telah dilakukan sebelumnya maka dapat disimpulkan bahwa Perlakuan Akuntansi Terhadap Penerimaan dan Pengeluaran Kas pada LPD Desa Pakraman Dharmajati Tuakad Mungga sudah sesuai dengan SAK dan teori yang berlaku umum. Hal ini bias dilihat :

a) pengakuan atau pencatatan yang dilakukan LPD Desa Pakraman Dharmajati Tukadmungga dilakukan dengan metode cash basi yaitu Pengakuan penerimaan dan pengeluaran kas pada LPD diakui sebesar jumlah kas atau uang yang diterima dan jumlah kas yang dikeluarkan.

b) Pengukuran dan penilaian LPD Desa Pakraman Dharmajati Tukadmungga menggunakan asas biaya historis yaitu aset dicatat sebesar pengeluaran kas atau setara kas yang dibayar atau sebesar nilai wajar dari imbalan yang diberikan untuk memperoleh aset tersebut pada saat perolehan.

c) pengidentifikasian dilakukan sebelum membuat laporan keuangan dengan melihat buktibukti yang ada seperti BKM, BKK, nota, kwitansi dan dokumen lainnya agar kas yang ada di laporan keuangan menjadi relevan.

Laporan keuangan yang dihasilkan oleh LPD Desa Pakraman Dharmajati Tukadmungga yaitu Laporan Neraca dan Laporan Laba Rugi. Laporan keuangan yang dibuat sudah sesuai dengan PSAK, dalam hal ini bisa dilihat Laporan Neraca kas disajikan terpisah dengan aktiva lancar lainnya dan dalam Laporan Laba/Rugi LPD Desa Pakraman Dharmajati Tukadmungga yang dibuat hanya membandingkan antara pendapatn dan biaya-biaya yang dikeluarkan Oleh LPD setiap harinya.

\section{Daftar Pustaka}

http://www.mediafire.com/download/k31m4u52jhdicu5/PSAKterbaru.rar

(http://www.balipost.co.id/balipostcetak/2006/12/18/o2.htm)

(http://www.balisaja.com/2011/02//pd-penyangga-adat-dan-budaya-bali.html) 